\title{
CORROSION RESISTANCE OF MECHANICALLY ALLOYED 14\%Cr ODS FERRITIC STEEL
}

\author{
Zbigniew OKSIUTA*, Ewa OCH*
}

*Faculty of Mechanical Engineering, Bialystok University of Technology, ul. Wiejska 45c, 15-351 Białystok, Poland

z.oksiuta@pb.edu.pl, e.och@pb.doktoranci.edu.pl

\begin{abstract}
The paper presents results of the corrosion resistance of mechanically alloyed oxide dispersion strengthened $14 \% \mathrm{Cr}$ ferritic stainless. The oxide dispersion strengthened steel was prepared by means of the powder metallurgy route that consists of mechanical alloying of a pre-alloyed argon atomized steel powder (Fe-14Cr-2W-0.3Ti) with $0.3 \mathrm{Y} 2 \mathrm{O} 3$ (wt\%), followed by HIPping at $1150^{\circ} \mathrm{C}$ and annealing at $850^{\circ} \mathrm{C}$ for $1 \mathrm{~h}$. The density of ODS ferritic steel after consolidation was about $99.0 \%$ of theoretical alloy density. The potentiodynamic corrosion tests were performed for $1 \mathrm{~h}$ and $24 \mathrm{~h}$ of material exposure in a physiological saline solution. For comparison the 316 LV austenitic stainless steel was also examined. The obtained results revealed that both materials were in a passive stage, however the lower current corrosion density was measured for 316 LV steel. On the contrary, the austenitic stainless steel exhibited unstable chemical processes at the passive region. On the surface of both materials localized pitting corrosion was observed with different morphology of the cavities. A broken oxide scale with poor adhesion to the ferritic steel matrix with large number of density of localized corrosion attack was observed on the surface of the ODS steel.
\end{abstract}

Key words: ODS Ferritic Steel, 316 LV Austenitic Stainless Steel, Potentiodynamic Corrosion Tests, Pitting Corrosion Resistance

\section{INTRODUCTION}

Oxide dispersion strengthened (ODS) ferritic steels belongs to the group of stainless steels with very good creep properties and oxidation resistance (Hoelzer et al., 2000). This is due to addition of $\mathrm{Y}_{2} \mathrm{O}_{3}$ nanoparticles which stabilize the grain size and dislocation motion at elevated temperature. These materials are envisage to be used as claddings for a water-cooling fast breeder nuclear reactor and in a light water reactor as a cross-cutting material for different nuclear systems or as a tubular heat exchanger. Despite numerous attempts, the powder metallurgy (PM) route is the remains the only method of producing the ODS ferritic alloys. Residual porosity always presented in such kind of materials as well as excess oxygen content may have an influence of their corrosion properties.

It is well known that the corrosion resistance in aquatic environment depends on the chromium concentration in steels (Cho et al., 2004; Ukai et al., 1998), due to the formation of $\mathrm{Cr}_{2} \mathrm{O}_{3}$ passive layer that suppress and slows the corrosion rate, as well as that the austenitic stainless steels exhibit better corrosion resistance in comparison with the ferritic stainless steels. This is due to the higher $\mathrm{Cr}, \mathrm{Ni}$ and $\mathrm{Mo}$ content commonly used in austenitic steels production that stabilize the face-centered cubic (fcc) structure and reduces the risk of crevice and pitting corrosion (Ollivier-Leduc et al., 2011). Nickel and molybdenum addition for the ODS ferritic steels is forbidden when applying this material in new generation of fusion and fission power plant reactors. The molybdenum increases corrosion resistant properties of the stainless steels, particularly pitting and crevice corrosion in chloride environments. Absence of $\mathrm{Ni}$, may influence the corrosion resistance of the ODS ferritic steel by accelerating localized corrosion. Also, very important issue is carbon, oxygen and nitrogen content in the stainless steels since these elements create the chromium-rich precipitations which noticeably diminish the steels ability to passivation.

The advantage of using the ODS ferritic steels in the nuclear reactor application, instead of the austenitic stainless steels, is their superior thermal stability (a lower thermal expansion coefficient), significant irradiation resistance and comparable thermal conductivity. On the contrary, the 316 stainless steels have superior welding characteristics and fracture toughness at cryogenic temperatures.

Since, the literature data about corrosion resistance of the ODS ferritic steels in aquatic environment is very limited, the potentiodynamic corrosion tests of these grade of materials were performed here. The obtained results were compared with the conventional austenitic stainless steel 316 LV.

\section{EXPERIMENTAL PROCEDURE}

The ODS ferritic steel was prepared by mechanical alloying (MA) in a planetary ball mill from a pre-alloyed, argon atomised Fe-14Cr-2W-0.3Ti (in wt.\%) powder with $0.3 \% \mathrm{Y}_{2} \mathrm{O}_{3}$ nanoparticles under hydrogen atmosphere (Oksiuta 2011). Further consolidation consisted of hot isostatic pressing (HIP) followed by an annealing at $850^{\circ} \mathrm{C}$ for $1 \mathrm{~h}$ in argon, and cooling slowly with furnace up to ambient temperature. The density of ODS ferritic steel after HIPping was about $99.0 \%$ of theoretical density $\left(\rho_{\mathrm{t}}=7830 \mathrm{~kg} / \mathrm{m}^{3}\right)$ and residual pores were observed. The austenitic stainless steel, AISI 316 LV grade (ASTM F899-12b Standard Specification) was in asreceived state. The chemical composition of both materials is summarised in Tab. 1. Three specimens for each material, with a size of $10 \mathrm{~mm}$ in diameter and $5 \mathrm{~mm}$ thickness were surface grounded using abrasive paper \#2400 and mechanically polished with an alumina suspension and ultrasonically cleaned in acetone then ethanol and dried.

The corrosion behaviour of tested materials was determined 
by potentiodynamic polarization method by means of the VoltaLab 21 set equipped with Volta Master 4 software. Using the software the value of the corrosion potential $\left(E_{c o r}\right)$, the current corrosion density (I $I_{c o r}$, Tafel method according to the first Stern equation), the corrosion resistance (Rp), the breakdown (pitting) potential $\left(E_{b}\right)$ and the corrosion rate $\left(C_{R}\right)$ were determined. For this purpose, a three-electrode electro-chemical cell was used with the saturated calomel reference electrode (SCE) and comparative platinum counter electrode with an area of contact equal to $128 \mathrm{~mm}^{2}$. The contact area of the material exhibited to the test was $28.3 \mathrm{~mm}^{2}$. The samples were polarized in the potential range of about $-1 \mathrm{~V}$ to $4 \mathrm{~V}$ with set rise of potential rate of $1 \mathrm{mV} / \mathrm{s}$. An open circuit potential of steels was studied after one hour of exposure, but due to the unstable potential, the time of the study was extended up to 24 hours. Corrosion tests were performed in a physiological saline solution at the temperature of $37 \pm 1^{\circ} \mathrm{C}$.

Tab. 1. Chemical composition of the ODS ferritic steel (wt.\%)

\begin{tabular}{|c|c|c|c|c|c|c|c|c|c|}
\hline Steel & $\mathrm{Cr}$ & $\mathrm{W}$ & $\mathrm{Mo}$ & $\mathrm{Ti}$ & $\mathrm{Mn}$ & $\mathrm{Ni}$ & $\mathrm{O}$ & $\mathrm{C}$ & $\mathrm{Si}$ \\
\hline ODS & 13.5 & 1.9 & 0.02 & 0.32 & 0.38 & 0.13 & 0.2 & 0.043 & 0.35 \\
\hline $316 \mathrm{~L}$ & 16.5 & - & 2.25 & 0.01 & 1.87 & 10.6 & 0.01 & 0.030 & 0.5 \\
\hline
\end{tabular}

\section{RESULTS AND DISCUSSION}

General microstructure of the ODS ferritic steel is presented in Fig. 1a and 1b. The ODS steel has a ferritic (bcc) structure with precipitations, mainly chromium oxides as well as the larger pores. From OM image the prior particle grains (PPG) with the size of about $45 \mu \mathrm{m}$ were observed, what correspond well with an average powder particle size measured after mechanical alloying of the ODS steel powder (Oksiuta et al., 2011). The oxide precipitations were also clearly observed on a cross section of the ODS steel, mainly decorated grain boundaries (see Fig. 1c).
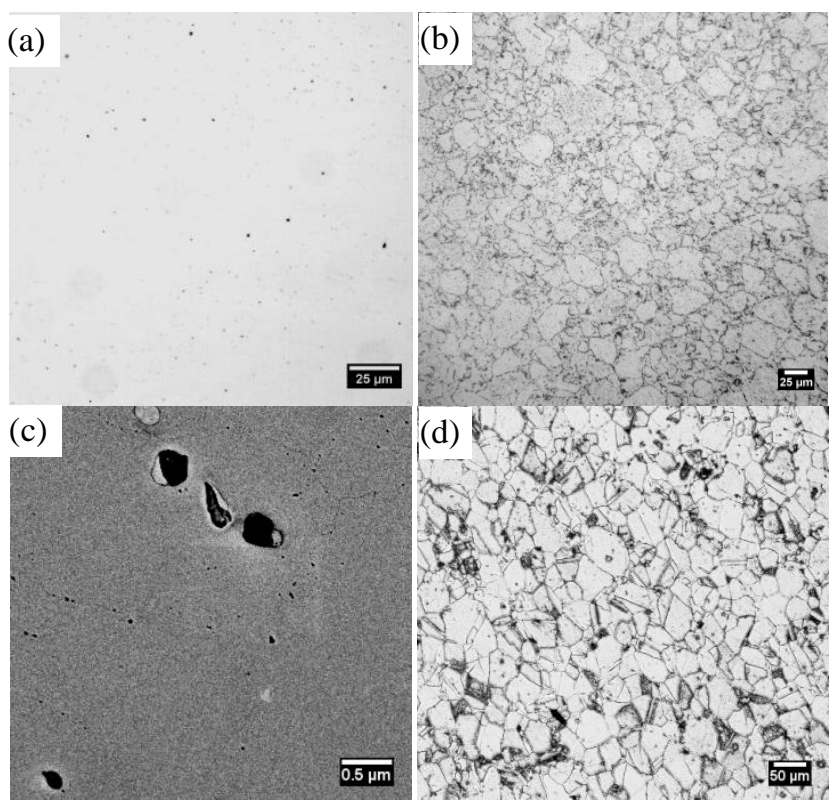

Fig. 1. Microstructure of the tested steels; a) porosity on the polished surface of the ODS ferritic steel, b) OM image of the ODS ferritic steel after etching, c) SEM image of oxide precipitations and d) OM image of the $316 \mathrm{LV}$ steel
The austenitic stainless steel in as-received state has a typical fcc-phase structure with an average grain size of $\sim 35 \mu \mathrm{m}$ and twins as well as chromium carbide precipitations (see Fig. 1d).

Typical potentiodynamic polarization curves of both steels are shown in Fig. 2, and the mean values of the polarization data are summarized in Table 2 (average of the three specimens).

The results of polarization tests of both materials show a large active peak consisting of a low current passive region for the scan performed towards the higher potential direction. The corrosion potential at active area is slightly noble for the ODS ferritic steel in comparison with the 316 LV counterpart. The anodic peak at approximately $-420 \mathrm{mV}$ can be attributed to the oxidation of $\mathrm{Cr}$ to the thermodynamically more stable form of $\mathrm{Cr}^{3+}$ (Carmezim et al., 2005).

Tab. 2. Electrochemical parameters calculated from the polarization tests of the ODS ferritic and 316 LV steels

\begin{tabular}{|c|c|c|c|c|c|}
\hline Steel & $E_{\text {cor }}[\mathrm{V}]$ & $R_{P}\left[\mathrm{k} \Omega \mathrm{cm}^{2}\right]$ & $\begin{array}{c}\mathrm{i}_{\text {corr }} \\
{\left[\mu \mathrm{A} / \mathrm{cm}^{2}\right]}\end{array}$ & $C_{R}[\mu \mathrm{m} / \mathrm{Y}]$ & $E_{P}[\mathrm{~V}]$ \\
\hline ODS & -0.375 & 6.54 & 4.115 & 46.885 & 1.107 \\
\hline $316 \mathrm{~L}$ & -0.427 & 47.95 & 0.711 & 8.319 & 0.504 \\
\hline
\end{tabular}

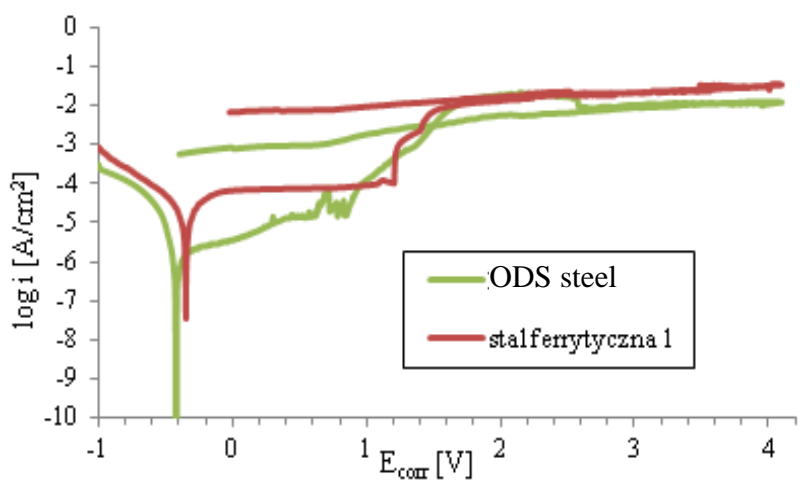

Fig. 2. Typical example of the potentiodynamic polarization curves measured on the ODS and $316 \mathrm{LV}$ steels

On the contrary, the current density in the passive region is significantly higher for the ODS ferritic alloy, however this material exhibits better the breakdown potential value $\sim 1.107 \mathrm{~V}$. A flat shape of the curve running in the passive area, contrary to the 316 LV steel (see Fig. 2), revealed that an oxide film in the ferritic steel is more protective than in the austenitic one, where a continuous chromium oxidation process takes place. For 316 LV a typical potential value for the austenitic stainless steels of about $0.5 \mathrm{~V}$ was measured. Interestingly, above these breakdown potentials both materials show fast increase in the current density which is characteristic to the transpassive oxidation of chromium from $\mathrm{Cr}^{3+}$ to $\mathrm{CrO}_{4}{ }^{2-}$ (Tyurin, 2003). When the corrosion potential reaches a value of $\sim 1.6 \mathrm{~V}$, the passive state with a current plateau of both materials was achieved up to $\sim 4 \mathrm{~V}$ where the test was interrupted and the reverse scan was begun. It is worth to note that no repassivation potential for both tested alloys was observed.

The 316 LV steel has more than seven times higher corrosion resistance $\left(R_{P}\right)$ and six times reduced the mean corrosion rate value $\left(C_{R}\right)$, in comparison with the ODS alloy tested at the same conditions, (see Table 2). This is probably due to different chemi- 
cal composition ( $\mathrm{Cr}, \mathrm{Ni}, \mathrm{Mo}$ and $\mathrm{O}$ content) and the presence of the large chromium oxides observed at the grain boundaries of the ODS steel.

The surface morphology of the tested samples exposed in the saline solution for $24 \mathrm{~h}$ is shown in Fig. 3.
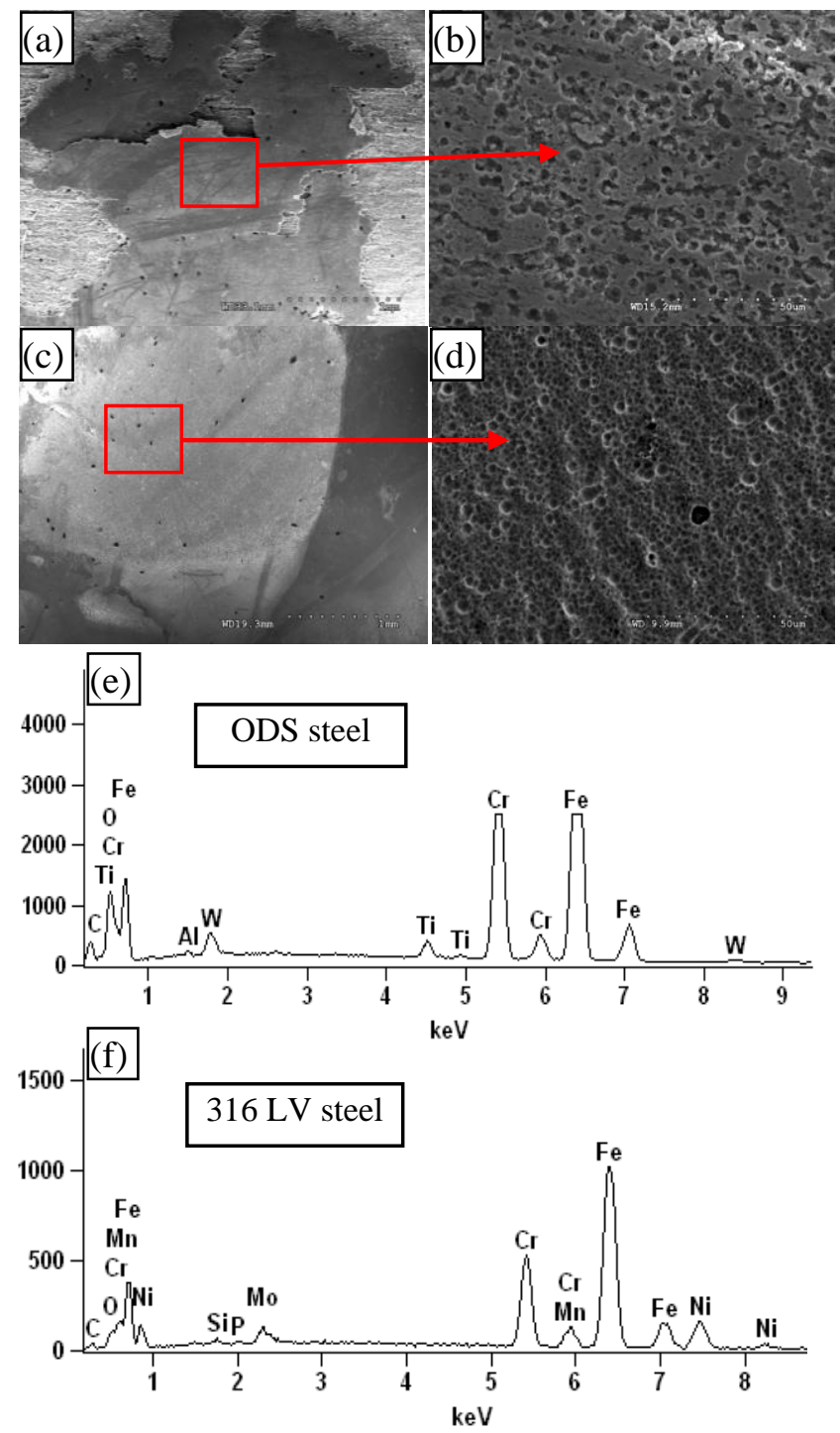

Fig. 3. SEM images of the surface of both materials after corrosion tests: a) and b) the ODS ferritic steel after $24 \mathrm{~h}$ of exposure time, c) and d) the $316 \mathrm{LV}$ stainless steel exposure for $24 \mathrm{~h}$ and $e$ ) and f) the SEM-EDS analysis of the ODS and 316 LV steels, respectively

Short time of exposure (for $1 \mathrm{~h}$ ) in the physiological saline solution did not cause any changes on the surface of the ODS steel (results not presented here). SEM images, completed by EDS analysis revealed, that after exposures for $1 \mathrm{~h}$ singular pits covered the surface of the ODS steel. In contrast, a fast corrosion rate was developed for $24 \mathrm{~h}$ of exposure. After a prolonged exposing time, a broken oxide scale on the surface of the ODS specimen was clearly visible (see Fig. 3b), and a large number density of small localized corrosion cavities (up to $5 \mu \mathrm{m}$ in diameter), penetrating grain boundaries, which were the most active corrosion areas, were observed. The SEM-EDS analysis also revealed that the scale consisted of complex Cr-Ti-rich oxide layer and did not show significant variation in the chemical composition. Also, it should be emphasize that the oxide layer on the ODS steel was fragile and had poor adhesion to the ferritic steel substrate what was also confirmed by the observations of the corrosion products found in the saline solution.

There is a distinct contrast between the surface morphology formed on the 316 LV and ODS ferritic steel tested at similar corrosion conditions. For the $316 \mathrm{LV}$ steel two kinds of corrosion pits can be distinguished. Low magnification SEM images in Fig. $3 \mathrm{c}$ revealed larger pits with an average size of $\sim 25 \mu \mathrm{m}$ in diameter and with low number density of $\sim 2.0 \times 10^{4} / \mathrm{m}^{2}$. The second type of pits, observed at higher magnification in Fig. 3d, has shallow and more uniform morphology, which looks like a general corrosion, equally covering the entire area of the specimen. This may lead to the assumption that austenitic steel has not uniform distribution of the main alloying elements and their segregation can locally cause severe oxidation and pitting corrosion attack. This is in a good accordance with observations of a steady increase in the current density in the passive region of the $316 \mathrm{LV}$ steel.

Nevertheless, it seems that from the electrochemical point of view, comparative analysis shown that better corrosion resistance has the 316 LV steel than the ODS ferritic alloy since the former material exhibits lower current density and the corrosion rate values. This is mainly due to the higher amount of corrosion protective elements, such as $\mathrm{Cr}, \mathrm{Ni}$ and Mo used for production the austenitic steel and lower oxygen content.

The results presented here also shown that the main type of damage observed on the surface of both materials after corrosion testing is pitting. Resistance of the steels to this kind of corrosion can be predicted from the chemical composition of tested materials by means of the pitting resistance equivalent (PRE) parameter expressed as (Kim et al., 2002):

$\mathrm{PRE}=\% \mathrm{Cr}+3.3 \%(\mathrm{Mo}+0.5 \mathrm{~W})+16 \% \mathrm{~N}$

The higher the PRE parameter the better pitting corrosion resistance of the steels. Calculated from Eq. (1) the PRE parameter exhibited $\sim 42 \%$ higher value for the 316 LV steel in comparison with the ODS alloy, $24.4 \%$ and $16.8 \%$, respectively. This confirms why the 316 LV steel demonstrate better pitting corrosion resistance than the ODS ferritic steel.

\section{SUMMARY}

The potentiodynamic corrosion resistance of the ODS ferritic steel and 316 LV austenitic stainless steels was studied. As expected, the results presented in this work shown that better corrosion resistance has austenitic stainless steel, due to larger content of the pitting protective alloying elements. However, the $316 \mathrm{LV}$ steel has the lower breakdown potential than the ODS ferritic steel and the unstable shape of the curve running in the passive region, which means that the surface of the former alloy is undergoing a slow oxidation process.

The microstructural characterization of the surface layer after corrosion tests revealed that there is a distinct difference between the surface morphology of both alloys. A broken oxide scale with poor adhesion to the ferritic steel matrix and with a large number density of localized corrosion attack was observed on the surface of the ODS ferritic steel. Shallow and more uniform pits with a surface looking more like a general corrosion were observed on 
the surface of the 316 LV austenitic steel. However, in this material singular, deeper pits were also detected.

Despite the higher current density as well as the higher corrosion rate measured for the ODS ferritic steel this alloy manufactured by means of PM route exhibited a quite good corrosion resistance. To improve pitting corrosion resistance in this alloy the oxygen content should be reduced, what can decrease the number density of the oxide precipitations located at the grain boundaries.

\section{REFERENCES}

1. ASTM F899-12b Standard Specification for Wrought Stainless Steels for Surgical Instruments.

2. Carmezim M. J. (2005), Capacitance behaviour of passive films on ferritic and austenitic stainless steel, Corrosion Science, No. 47 581-591.

3. Cho H. S. et al. (2004), Corrosion properties of oxide dispersion strengthened steels in super-critical water environment, Journal of Nuclear Materials, No. 329-333, 387-391.

4. Hoelzer D. T et al. (2000), A microstructural study of the oxide scale formation on ODS Fe13Cr steel, Journal of Nuclear Materials, No. 283-287, 1306-1310.

5. Kim J. S. (2002), Effect of alloying elements on the contact resistance and the passivation behaviour of stainless steels, Corrosion Science, No. 44, 635-655.
6. Oksiuta Z. (2011), Microstructural changes of ODS ferritic steel powder during mechanical alloying, Acta Mechanica et Automatica, Vol. 5, No. 2, 74-78.

7. Oksiuta Z. et al. (2011), Influence of $\mathrm{Y}_{2} \mathrm{O}_{3}$ and $\mathrm{Fe}_{2} \mathrm{Y}$ additions on the formation of nano-scale oxide particles and the mechanical properties of an ODS RAF steel, Fusion Engineering and Design, No. 86, 2417-2420.

8. Ollivier-Leduc A. (2011), Study of selective oxidation by means of glow discharge optical emission spectroscopy, Corrosion Science, $53(2011) 1375 \div 1382$.

9. Tyurin A. G. (2003), Thermodynamic Assessment of the Effect of Chromium and Molybdenum on the Passivability of Nickel-Base Alloys, Protection of Metals, Vol. 39, No. 6, 568-574.

10. Ukai S. et al. (1998), R\&D of oxide dispersion strengthened ferritic martensitic steels for FBR, Journal of Nuclear Materials, No. 258-263, 1745-1749.

This work was supported by the Bialystok University of Technology, a grant No. W/WM/21/2013. 